\title{
Rental depreciation and capital expenditure in the UK commercial real estate market, 1993-2009
}

Article

Accepted Version

Crosby, N., Devaney, S. and Law, V. (2012) Rental depreciation and capital expenditure in the UK commercial real estate market, 1993-2009. Journal of Property Research, 29 (3). pp. 227-246. ISSN 1466-4453 doi:

https://doi.org/10.1080/09599916.2012.679009 Available at https://centaur.reading.ac.uk/28035/

It is advisable to refer to the publisher's version if you intend to cite from the work. See Guidance on citing.

To link to this article DOI: http://dx.doi.org/10.1080/09599916.2012.679009

Publisher: Routledge

Publisher statement: Crosby, N., Devaney, S. and Law, V. (2012) Rental depreciation and capital expenditure in the UK commercial real estate market, 1993-2009, Journal of Property Research; 29 (3): 227-246. DOI 10.1080/09599916.2012.679009 ISSN 0959-9916 print ISSN 1466-4453 online.

All outputs in CentAUR are protected by Intellectual Property Rights law, including copyright law. Copyright and IPR is retained by the creators or other copyright holders. Terms and conditions for use of this material are defined in the End User Agreement. 


\section{CentAUR}

Central Archive at the University of Reading

Reading's research outputs online 


\title{
Rental Depreciation and Capital Expenditure in the UK Commercial Real Estate Market, 1993-2009.
}

\author{
Neil Crosby * \\ Steven Devaney+ \\ Vicki Law* \\ *School of Real Estate and Planning \\ Henley Business School \\ University of Reading \\ Whiteknights \\ Reading \\ RG6 6UD \\ +University of Aberdeen Business School \\ Edward Wright Building \\ Dunbar Street \\ Old Aberdeen \\ AB24 3QY
}

This is an Accepted Manuscript of an article published by Taylor \& Francis in Journal of Property Research on 04/05/2012, available online:

http://www.tandfonline.com/10.1080/09599916.2012.679009

\section{Acknowledgements}

The authors acknowledge the funding for this and related projects from the Investment Property Forum over a number of years and the provision of data by CBRE and Investment Property Databank, without which this research would not have been possible. 
Rental Depreciation and Capital Expenditure in the UK Commercial Real Estate Market, 1993-2009.

\section{Abstract}

This paper identifies long term rental depreciation rates for UK commercial properties and rates of capital expenditure incurred to offset depreciation over the same period. It starts by reviewing the economic depreciation literature and the rationale for adopting a longitudinal method of measurement, before discussing the data used and results. Data from 1993 to 2009 is sourced from Investment Property Databank and CBRE real estate consultants. This is used to compare the change in values of new buildings in different locations with the change in values of individual properties in those locations.

The analysis is conducted using observations on 742 assets drawn from all major segments of the commercial real estate market. Overall rental depreciation and capital expenditure rates are similar to those in other recent UK studies. Depreciation rates are $0.8 \%$ pa for offices, $0.5 \%$ pa for industrial properties and $0.3 \%$ pa for standard retail properties. These results hide interesting variations at a segment level, notably in retail where location often dominates value rather than the building. The majority of properties had little (if any) money spent on them over the last 16 years, but those subject to higher rates of expenditure were found to have lower depreciation rates.

\section{Keywords:}

Capital Expenditure; Commercial Property; Depreciation; Obsolescence; Rental Values 
Rental Depreciation and Capital Expenditure in the UK Commercial Real Estate Market, 1993-2009.

\section{Introduction}

Property has to compete with other assets in the multi asset portfolio and the case for property must take account of any financial or asset based issues which make it in any way different to the competing assets. Although asset allocation models tend to suggest that it should form a significantly higher proportion within investment portfolios than its typical allocation, property and its performance figures are treated with some suspicion for a variety of reasons (see, for example, Hamelink and Hoesli, 2004). The heterogeneous nature of the assets, illiquidity, the lack of divisibility and the reliance of indices on valuations have all been cited. Another asset based issue is the impact of depreciation, often related to obsolescence, and a number of studies have sought to identify its impact.

Depreciation is also important within property appraisals, which need to take explicit account of both rental depreciation and capital expenditure (Baum and Crosby, 2007). Depreciation affects the choice of discount rate and the growth projections. Appraisal models can be used for acquisition/sale and asset management decision-making, and these decisions require some element of the life cycle of the site and buildings to be assessed (either explicitly in the cash flow or implicitly in the exit yield). Furthermore, depreciation rates are increasingly required for bank lending decisions. Market valuations are sometimes subject to special assumptions including valuing the building assuming it is at the end of the loan, i.e. 10 years older for a 10 year loan. Even if this appraisal is based on current value levels, the impact of the passage of time on rents and yields needs modeling, and depreciation rates inform these adjustments.

Finally, depreciation is of relevance to investors in indirect real estate. Apart from its influence on the values and growth prospects of vehicle assets, capital expenditure will impact on the income that can be distributed to the share or unit holders. Vehicles must be able to manage depreciation effectively, an issue that is particularly important where their actions are constrained by distribution rules or other restrictions laid down in return for tax transparency. Therefore, information on depreciation and expenditure rates informs debates about how such vehicles should be structured and contributed to the debate in the UK on creating a REIT-type vehicle (IPF, 2004; Baum and Devaney, 2008). 
This discussion highlights the need for commercial real estate depreciation to be studied. The objectives of this particular paper are to identify the theoretical and practical issues surrounding cross-sectional and longitudinal methods for measuring depreciation rates, to re-examine long term rates of rental depreciation and capital expenditure for the UK using a robust longitudinal framework and, finally, to test the impact of capital expenditure on rental depreciation rates. First, it reviews the depreciation literature, examining questions of definition and measurement. It then sets out reasons for the adoption of a longitudinal approach and identifies the data used to determine depreciation and expenditure rates over a 16 year period from 1993 to 2009. After this, the paper discusses the results of the empirical work before concluding with regard to findings, limitations and areas for further investigation.

\section{Literature Review}

A number of UK based studies have produced depreciation rates for one or more types of commercial real estate, commencing with Salway (1986) and followed by JLW (1987), Baum (1991; 1997), Barras and Clark (1996), CEM (1999), Turner (2001), IPF (2005) and Dunse and Jones (2005). Several of these studies are reviewed in detail by Dixon et al. (1999). In addition, Baum and Turner (2004) and IPF (2010) examined depreciation for office markets in Europe, whilst, for the United States, Colwell and Ramsland (2003) have recently studied retail property and Corgel (2007) has examined the depreciation of hotels.

The studies of UK commercial real estate have been carried out for different time periods and locations. Although such differences would be expected to cause the results of these studies to vary, they have been described as producing fairly consistent results. Turner (2001), in reviewing the studies by Salway (1986), Baum (1991) and Barras and Clark (1996), comments that “... there is remarkable consistency between the three studies in terms of (rental value) annual depreciation estimates". Meanwhile, Hoesli and MacGregor (2000: 169), noting the differences in approach, timing and data sources, state that "the various estimates of depreciation ... (have) ... a reasonable degree of consistency".

Law (2004) examined the methods and results of seven UK office depreciation studies carried out in the period up to 1999. She found that these studies included a wide variety of measurement methods and data transformations and that there was no agreed definition of depreciation, hence the variety of approaches. Applying these methods to a consistent dataset and time period, she found that the apparent consistency of results was an illusion; the range in rental depreciation rates generated by the different approaches was three times that apparent from the reported 
rates (an increase from $2.25 \%$ to over $6 \%$ p.a.). Therefore, it is important to examine both concept and method in detail to derive an appropriate and robust measurement framework.

\subsection{Definition and Measurement Framework}

The measurement of depreciation is grounded in the fields of accountancy and economics. In the former case, depreciation has developed as a consumption concept whereby the accounts record the amount of asset value that is assumed to have been consumed over the accounting period. The current definition of depreciation in UK accounting rules is "the measure of the cost or revalued amount of the economic benefits of the tangible fixed assets that have been consumed during the period" (FRS15, paragraph 2). This gives some scope for asset revaluations, but, in general, accounting depreciation does not reflect actual changes in asset values and, in the UK, these rules are not applied to properties held as investments. Therefore, references in the real estate literature to the accounting definition of depreciation (e.g. Bowie, 1984; Salway, 1986) are misleading.

In economics, an extensive literature on economic depreciation has developed, which attempts to estimate actual changes in value over an asset's life. The articles of Hulten and Wykoff (1976, 1981a, 1981b) are widely recognized as seminal in this respect and these contain estimates of depreciation rates for assets as varied as furniture, tractors, construction machinery, automobiles and aircraft, as well as industrial and commercial buildings. Citing Hotelling (1925), they define depreciation as "the rate of change of asset price with age at a point in time" (1981a: 370) and adopted a cross-sectional approach for its measurement, comparing the prices of assets of different ages at particular points in time. Since then, further work has re-examined some of these asset types and extended the study of depreciation into new areas, such as computers (see Jorgenson, 1996).

This literature has identified a number of important issues surrounding the measurement and interpretation of depreciation rates, including the effect of retirements, the relationship between prices and rents of used assets, and whether depreciation is a phenomenon that occurs with aging or over time. In the latter case, the literature agrees that change in value/price by both age and time occurs, but typically it defines depreciation in relation to the former. The different relationships are identified by Hulten and Wykoff (1996); first, that of change in value due to age; second, change in value due to time; and, third, change in value due to age and time. The first is defined by them as depreciation and implies a cross-sectional approach to measurement. Hulten and Wykoff then refer to change in valuation over time as a revaluation effect. Hotelling (1925) 
defines depreciation as the rate of decrease of value and subsequently refers to both time and age effects. This is consistent with the approach used in the UK real estate depreciation studies.

Other important issues are the roles of maintenance expenditure and replacement investment. These have been identified as choices in response to deterioration and external factors, such as new asset prices, taxation policies and interest rates (Feldstein and Rothschild, 1974; Nelson and Caputo, 1997). Depreciation is affected by decisions on the extent of maintenance and whether or not to replace assets, both at an asset level and an aggregate level if there is a systematic response to particular events, e.g. a change in taxation policy. In the case of real estate, expenditure may contain elements of both maintenance and replacement in order to arrest any decline in value, with the ultimate step being that of replacing the depreciated building with a new one (Blazenko and Pavlov, 2004). Thus, expenditure is central to interpreting depreciation rates, but it has received little attention in much of the commercial real estate literature. In contrast, studies of residential property have given this issue more consideration (e.g. Leigh, 1980; Knight and Sirmans, 1996).

The economic literature distinguishes between deterioration and obsolescence as major causes of price depreciation, whilst real estate studies have further distinguished types of obsolescence, such as functional, aesthetic, legal, social, physical and environmental obsolescence (e.g., Baum, 1991; Golton 1989; Mansfield and Pinder, 2008). Location can also be an important factor and its influence has been described, for instance, as "a loss in value due to factors external to the property" (Wurtzebach and Miles, 1984). Yet, location factors can also lead to appreciation and some of the identified causes of locational obsolescence can cause assets to increase in value even if the building element is depreciating. Depreciation has been universally measured at the property level in UK studies to include site and building value owing to the difficulties of objectively distinguishing building from land value. Causes of depreciation, including the impact of location, are not the main focus of this paper, but they are important in interpreting any measures of depreciation, as is recognized later.

The UK real estate literature discusses the concept of relative depreciation, i.e. measurement against a benchmark. This is done to control for general movements in value over time. Whilst the literature is consistent in its approach to depreciation as a relative concept, it differs in its understanding of what depreciation is relative to, being variously defined as relative to a market benchmark (Baum, 1997; Barras and Clark, 1996), new properties (Salway, 1986), and prime property but not necessarily new (Baum, 1991; JLW, 1987). The choice of benchmark is central to the definition of depreciation and its measurement, and should ensure that the change being measured is due to depreciation and excludes other influences. It is also one of the factors that 
created major differences between depreciation rates found within past UK studies carried out in the 1980s and 1990s (Law, 2004).

Market benchmarks of rental or capital value growth are normally measured using held samples of properties. Therefore, they include depreciation as they comprise a sample which ages over the measurement period, regardless of the shortness of that period. ${ }^{1}$ Changes in portfolio makeup are only incorporated at the end of each period and effective from that point forward. This is illustrated for the IPD indices in the UK by IPF (2005). In contrast, prime indices constructed on a hypothetical rather than 'top rent' basis do not include depreciation as they are based on the rental value or yield of a hypothetical new property. Furthermore, the use of a continually prime index allows the resultant depreciation rate to account for obsolescence. However, use of a prime index when a sample is comprised of properties in non-prime locations may misstate depreciation as there may be relative differences in performance between prime and non-prime locations in different market states.

In summary, consensus exists in the UK real estate literature that depreciation is a relative fall in the value of a property, but confusion occurs around how that fall should be measured and what benchmark it is measured against. It has also presented depreciation as both a rental and capital concept, but distinct from the accounting and economic literature, it has focused mainly on measuring rental depreciation. This is because capital value change is complicated by other factors, most importantly changing lease structures through time, which impacts on valuations. ${ }^{2}$ Meanwhile, the economic depreciation literature raises the issue of the distinction between age and time. It is also an issue for the UK real estate studies, with depreciation defined both by age and time and measured by age and ageing over time using both cross sectional and longitudinal datasets. This is now explored further.

\footnotetext{
${ }^{1}$ For example, in a monthly rental growth index, the rental value of a fixed set of properties is measured at the beginning and end of the month and rental growth calculated accordingly. The growth rate is then chainlinked with those from adjacent periods to form a longer term index.

${ }^{2}$ For example, capitalisation rates could move upwards on account of the property depreciating through time, but also because the unexpired term of an existing lease was getting shorter. Therefore, any analysis of capital value depreciation needs to be undertaken using a dataset that includes lease details. These were not available within the current dataset as they are not recorded in the UK IPD prior to 1998.
} 
Longitudinal studies consist of a set of repeated observations of the same sample over time. For cross-sectional studies, data are collected at one point in time. Different cross-sections can be compared, but this differs from a longitudinal study in that the datasets for each cross-section will not consist of identical samples (Dixon et al., 1999). Cross-sectional analysis has been used by depreciation studies in order to isolate age as an explanatory variable of depreciation and is consistent with defining depreciation as a fall in value due to age.

However, a cross-sectional approach raises a number of problems. A cross-sectional analysis can be distorted should the point in time chosen be unrepresentative, i.e. a cross-section taken in a weak market could produce very different results from one in a strong market (Salway, 1986). This is acknowledged by Hulten and Wykoff (1996) who note that supply and demand shocks can alter the relative prices of differently aged assets. In addition, any sudden obsolescence would affect the result if the cross-section were taken just after a technological advance that impacted on property, but this would not necessarily be obvious from the results themselves (Salway, 1986). Conversely, the analysis could miss the effect of obsolescence if performed just before a major technological change (CEM, 1999).

Observations may not be evenly distributed across different ages. This is particularly likely in the case of commercial real estate, which is subject to distinct development cycles. As a consequence, rather than use a single age variable, several studies of real estate have had to adopt age bands and so depreciation rates are influenced by how the bands have been defined. This introduces another aspect by which studies can vary. Furthermore, the analysis will be influenced by the year in which the assets were built. So differences between properties of different ages may not be due to age alone, but also to differences in building regulations, fashion, technology or materials at the time the properties were built. Additional problems with a cross-sectional study are that depreciation is not tested over time (although repeated crosssections will address this) and that the role of expenditure is difficult to examine (Baum, 1991).

These criticisms can be addressed in longitudinal measurement. Controlling for all three effects of age, cohorts (groups) of properties from different eras and the time period requires longitudinal data. Longitudinal research can measure change in age as well as in time, but the interpretation differs from the age analysis achieved by a cross-sectional design. Age differences in a crosssectional design relate to differences between cohorts, in a longitudinal design, a case can be tracked from construction and therefore the effects of age within a cohort are measured. However, if longitudinal analysis is limited to one age cohort, e.g. tracking a set of buildings built 
in 1960, any depreciation observed cannot separate cohort effect from the effect of time period. In contrast, the use of a multiple cohort longitudinal analysis can be used to segment the data and explore all three factors of time, age, and cohort.

Longitudinal analysis is often difficult to implement given that used assets are not usually traded repeatedly. However, it is possible to conduct longitudinal studies for property investments owing to the requirement for some types of owner to produce regular asset revaluations as a surrogate for prices. Over long intervals, the sample size declines owing to retirements of assets that are no longer efficient to operate. This is a problem for segmenting the sample by age, location, or other attributes and because the measurement of depreciation rates using surviving assets may be biased. The latter phenomenon also affects the representation of older age groups within crosssectional analysis and, in that context, Hulten and Wykoff (1981a) proposed a correction that assumes the value of retired assets to be a fixed value (zero). This would be unreasonable in the case of our data (see below), where properties leave the dataset for a variety of reasons and not solely because they are ready for demolition and redevelopment, but the limitation of using surviving assets is considered further in the section that follows.

\section{Methods and Data}

The discussion suggests that the longitudinal approach to measurement of depreciation is the more theoretically sound method and this study has adopted that approach in order to identify long-term rental depreciation rates for UK commercial real estate. A definition of depreciation that has been suggested by Law (2004) and which is consistent with this approach is as follows:

"the rate of decline in rental/capital value of an asset (or group of assets) over time relative to the asset (or group of assets) valued as new with contemporary specification" (Law, 2004, p242).

Law has also proposed that the following measurement formula be adopted, which is consistent with this definition and approach:

$$
\mathrm{d}=1-\left(\frac{\sum \mathrm{R}_{\mathrm{t} 2}^{\mathrm{a}} / \sum \mathrm{R}_{\mathrm{t} 1}^{\mathrm{a}}}{\sum \mathrm{R}_{\mathrm{t} 2}^{\mathrm{b}} / \sum \mathrm{R}_{\mathrm{t} 1}^{\mathrm{b}}}\right)^{1 /(\mathrm{t} 2-\mathrm{t} 1)}
$$


where $d=$ the annual rate of depreciation, $R^{a}=$ asset rental value, $R^{b}=$ benchmark rental value, $\mathrm{t} 1$ = beginning of the measurement period and $\mathrm{t} 2$ the end of the measurement period.

The formula expresses the change in asset rental values between two points in time as a ratio and divides this by a similar ratio for the change in the value of the benchmarks between those same time points. The result is then adjusted for the number of time periods so that depreciation is expressed as a periodic (annual) rate. This is not meant to imply that the rate of depreciation is stable over the period. Instead, the formula should indicate a long term average depreciation rate that is not distorted by individual periods, although, in practice, it can be quite sensitive to market conditions at the start and end points, especially if benchmark and asset values reflect those conditions differently. ${ }^{3}$

The approach requires a held sample of properties for the period of analysis and a set of benchmarks for the value of new properties in the same location as the sample assets. In the former case, data for this study was provided by Investment Property Databank (IPD). The IPD UK database contains data on direct property investments held by major UK investment institutions, such as insurance companies, pension funds and UK REITs. Although these properties are institutionally owned, this does not mean that they are all prime properties; both prime and non-prime assets are present in the sample. The database can be segmented in a number of ways and the standard IPD Portfolio Analysis System (PAS) segments were used for this analysis with one modification; a split to examine standard retail properties in Central London separately from those in the rest of South East England as the rental performance of the former was notably stronger.

The time frame for this study is largely dictated by data availability. Creating a dataset in line with the definition and approach above is a lengthy and time consuming process. Having identified properties that are present in the dataset throughout any chosen timescale, these then must be matched individually with the closest benchmark data point. This process was undertaken for the study by IPF (2005) and that dataset was made available for the present study. The original data covered the period 1993 to 2003 and the time frame was extended relatively easily to 2009 .

The dataset has information on the rental values, capital values and amounts of capital expenditure for a sample of properties held continuously over the period 1993-2009. Rental and capital values are appraisal based, whilst capital expenditure amounts relate to non-recoverable capital spending by owners and exclude any sums (either maintenance or capital related) that

\footnotetext{
${ }^{3}$ Crosby et al. (2011) encounter this problem when analysing some mainland European real estate markets, but they demonstrate that the UK is relatively unaffected in this respect.
} 
were recoverable from the tenants in those properties. ${ }^{4}$ The dataset also contains a limited amount of descriptive data such as the location and floorspace of each asset and, in most cases, the date of construction or last major refurbishment. However, it does not have lease data, hence the inability to adequately measure capital value depreciation. The focus on buildings held within a single ownership is a constraint driven by the structure of the IPD databases, which do not track properties across institutional ownerships when they are traded.

Any buildings that were entirely redeveloped during the period were excluded from the analysis, as were assets that lacked a full set of values to end 2009, a suitable benchmark for the depreciation formula or were obvious outliers in terms of the input data that could not be explained. Meanwhile, 44 out of 742 cases were adjusted to reflect the fact that part purchase or part sale of these assets had occurred during the period. In such cases, both values and amounts of expenditure were grossed up to represent an entire asset in the years where they were only part owned.

One disadvantage of a longitudinal approach is the trade-off between sample size and length of study. In extending the IPF dataset to 2009, there were a number of retirements from the original data. This is illustrated in Table 1, which compares the size of the sample to that used in IPF (2005) for the period 1993-2003 and in relation to all assets present in the IPD database at end1993. Only $40 \%$ of the dataset from the earlier IPF study could be extended, the main reason being trading in the intervening years. Overall, 5\% of the IPD dataset as at 1993 are still in the same ownership in 2009, a $95 \%$ churn over 16 years. It is important to stress that these trades are not all retirements in the conventional sense of scrapping, but include sales between institutions as well as properties sold because they are no longer considered to be investment grade; even here, this does not imply that the asset will be immediately redeveloped.

\section{Insert Table 1 here}

Nonetheless, the issue of retirements raises questions about the representativeness of the sample and the potential for survivor bias. Table 2 reports the rental growth of the sample in each segment over 1993-2009 together with that shown by the comparable published IPD index in that period. It also reports average age for the sample assets alongside average ages from the IPD database at end 1993. The figures suggest that sample rental growth has been stronger by $0.5 \%$ p.a. overall and stronger within most segments, the exceptions being Shopping Centres and City of London offices. The sample appears to be more similar in terms of average age, with a bias to

\footnotetext{
${ }^{4}$ The classification of expenditure as either revenue or capital related is determined by data contributors (i.e. owners) with reference to standard reporting guidelines issued by IPD. Revenue expenditure typically refers to minor sums spent on fees, maintenance and upkeep.
} 
younger assets that is most marked in the regional office segments, whilst Central London offices are, surprisingly, notably older.

These differences must be borne in mind when interpreting the results that follow. Despite this, the results contain valuable contain valuable information concerning the rate at which properties held for the long term depreciate and the capital expenditure needed to contain depreciation rates to the reported levels. The rates and relativities are also suggestive of broader patterns relating to all investment properties.

\section{Insert Table 2 here}

The definition of depreciation given by Law (2004) suggests that ideal benchmarks for this analysis would be values of new buildings of the same type and in the same locations as the subject assets. Several potential sources of benchmark values were assessed in the light of this ideal and the data underlying the CBRE UK Rent and Yield Monitor was selected as the most appropriate owing to its basis and extensive geographical coverage. Every quarter, CBRE assess the rental value and capitalization rate of a hypothetical new or refurbished building of a standard size with the highest specification appropriate for the location in question (CB Richard Ellis, 2007). ${ }^{5}$ This source was also used by CEM (1999) and IPF (2005), and is discussed by Dixon et al. (1999). Despite some limitations outlined below, it enables a better comparison of the difference between rental growth in a location and that of individual properties in the same or similar location than some of the benchmarks used in other studies, which include indices or reference values for properties that are also depreciating.

From the total population of rent points, 401 high street / shopping centre locations, 150 office locations and 124 industrial locations could provide observations both at the end of 1993 and the end of 2009. Meanwhile, observations for 82 retail warehouse locations could be traced from end 1993 through to end 2006, after which point, changes in data collection methods and in locations monitored meant that further observations were not available on a consistent basis. Hence, retail warehouse depreciation rates were calculated to end-2006 only. Each property in the sample was matched to an appropriate rent point. Benchmark rental values were specified in per square foot terms and these figures were multiplied by the floorspace of the corresponding property to ensure that assets could be weighted accurately when producing segment rates.

\footnotetext{
${ }^{5}$ Normally, the data is only available in aggregated form, but the individual rental assessments for each rent point were made available by CBRE for this research.
} 
However, benchmark rents for standard retail locations were specified not only in per square foot terms, but also In Terms of Zone A (ITZA), whereas the floorspace of sample assets is stated on a Net Internal Area (NIA) basis. A rent ITZA reflects the value of the prime selling area at the front of a retail unit and is higher than a figure based on the NIA. Hence, multiplying an ITZA rent by the NIA will cause the estimated benchmark rent to be overstated. This does not distort the measurement of retail segment rates to any significant degree, but it does distort the influence of retail when combined with other segments, as this sector is then over-weighted in the denominator of (1). Therefore, an 'all property' depreciation rate has been estimated by weighting the segment rates by the relative value of each segment in the IPD index as at the end of 1993.

The other major element of calculation in this research relates to capital expenditure. Expenditure rates were measured for individual properties by summing capital expenditure over the period concerned and dividing this by the sum of a set of annual capital values or that of a set of rental values for that asset over that period. For example, if expenditure was monitored from January 1994 through to December 2009, it would be divided using capital values observed each December end from 1993 to 2008, these representing the capital invested at the start of each year. This procedure generates an average annual expenditure rate and it can be extended to produce segment level results by summing the relevant amounts and values across all properties in a segment. 'All property' rates of expenditure were then calculated in the same manner as the all property depreciation rate, discussed above.

\section{Results}

\subsection{Rental depreciation}

Table 3 presents rental depreciation rates on a per annum basis of the main UK commercial property segments over the period 1993-2009. It also shows the rental growth of the assets in each segment and their matching benchmarks. The overall rental depreciation rate, assuming a typical portfolio make-up as at 1993 , is just over half a percent per annum. Meanwhile, the pattern at the three sector level is unsurprising and is consistent with results from previous UK studies in that office buildings exhibit the most depreciation over time and standard retail properties show the least, with industrials between the two (CEM, 1999; IPF, 2005).

\section{Insert Table 3 here}


However, the sector level rates mask considerable variation at a segment level. For instance, there is no clear explanation for the marked regional variation in standard retail depreciation shown by Table 3. It might be expected that shops would show little rental depreciation, although it is plausible that the development of new retail schemes in some areas could lead other retail assets to depreciate if they cannot be similarly upgraded or the location pattern within the town has changed. Yet, some of these impacts would be as likely to lead to appreciation as depreciation. Hence, it is puzzling why depreciation should occur in locations across London and the South East, while appreciation is occurring in the Rest of UK.

It is possible that this is caused by limitations with the benchmarks. If ideal benchmarks were available, then appreciation would be highly unlikely, but, in using data from the Rent and Yield Monitor, some micro-location factors arising from differences in location between the sample buildings and rent points can affect the results. This is likely to be more critical in the case of retail, where rents are highly sensitive to location, than for other sectors. Hence, appreciation rates are possible, although it was expected that these effects would cancel out over large samples. Checks confirmed that the rate for Rest of UK was not generated by outliers in the dataset or by one particular location. In fact, appreciation was found for assets in several major regional retail centres such as Leeds, York, Manchester and Newcastle.

The sample of Shopping Centres has suffered almost no rental depreciation. This is consistent with previous research (IPF, 2005) and suggests that, where Shopping Centres were retained by their owners, this is in locations where they continue to be the benchmark asset. It must also be seen in the light of a relatively high rate of capital expenditure for this segment (see Table 5). In contrast, despite strong rental growth, Retail Warehouses experienced moderately high rental depreciation, again consistent with IPF (2005). This is understandable when considering the rapid evolution of the retail warehouse format in this period, as discussed by Jones (2009). He notes how early versions of this property type quickly became obsolete and the results here support this conclusion, with the sample consisting of early generation assets that had to compete against the development of newer formats in an expanding sector.

For the office and industrial sectors, there is regional variation in the results. However, in this case, the patterns are more consistent. The highest rental depreciation in each sector occurs in the Rest of UK area, whilst lower depreciation is found in London and the South East. This is plausible if, in the latter case, occupiers are paying a larger premium for the location relative to the characteristics of the building. Certainly, for both rental and capital values, land/location typically comprises a greater proportion of total value in high value areas such as London and South East England. This indicates the importance of segmenting results based on land to 
building value ratios. The difficulty with this is that the valuation data does not distinguish between the land and building components. Yet, the regional dimension in the present analysis gives some indication of how the land value ratio may affect results (apart from in retail), although this aspect is worthy of further research. ${ }^{6}$

However, the results for the Central London office markets are harder to explain. It could be assumed that land value ratios are higher in the West End, whilst the age of the sample is higher and the rental value growth over the period is also higher. All of these factors suggest that the West End should have a lower depreciation rate than the rest of the office market.

The results so far have been value weighted aggregate rates and do not indicate whether those rates are typical for assets in each segment. Headline segment rates could be skewed by the experience of the most valuable buildings and there could be considerable dispersion in results at the individual asset level. Table 4 reports the average and spread of individual depreciation rates. The mean and median figures in the table are similar in all cases, suggesting that the underlying distributions of depreciation rates are not strongly skewed, though the inter-quartile ranges indicate considerable dispersion in individual building outcomes. ${ }^{7}$ Meanwhile, the unweighted means in Table 4 are similar to the value weighted rates in Table 3. The main exception to this is Retail Warehouses, where the most valuable assets appear to have held down the segment level depreciation rate (of $0.9 \%$ ).

\section{Insert Table 4 here}

Figures 1 and 2 illustrate the rental depreciation rates found for different age cohorts within the industrial and office sectors. The figures suggest different patterns for each, with the younger industrial cohorts (built between 1984 and 1993) depreciating faster than the cohorts built before those dates. A similar pattern of higher depreciation in the early years was found in Baum's $(1991,141)$ cross-sectional study of industrial buildings. In contrast, the office properties do not show this profile; each cohort appears to depreciate similarly over the 16 year period. In offices, there is no discernable " $S$ " curve or mid life crisis effect suggested by Baum $(1991,104)$ and CEM (1999), where the property has a low deprecation rate in its early life, followed by significant depreciation in its middle age, before bottoming out in later life where one additional year makes very little difference to its value. However, the office results may be affected by the uneven

\footnotetext{
${ }^{6} \mathrm{~A}$ regional split would be less effective at showing this in retail because Zone A values can be higher in some northern UK cities than in the south and building tender prices are often lower.

${ }^{7}$ Nonetheless, the null hypothesis of a normal distribution in standard retail, office or industrial depreciation rates was rejected at the $5 \%$ level in all three cases and at the $1 \%$ level for the standard retail and industrial samples using the Jarque-Bera test.
} 
spatial distribution of properties of different ages in this dataset (indicated by Table 2). The sample size is too small to disaggregate age cohorts across regions.

\section{Insert Figure 1 and 2 here}

\subsection{Capital expenditure}

The results above give only a partial picture of the impact of depreciation on real estate performance because they are measured using some assets where owners spent money in order to maintain and improve them over time. Thus, these are net or 'managed' rates of depreciation, as they show the relative fall in rental value for buildings where spending has absorbed at least some of the depreciation impact. The true cost of depreciation to an investor will include this expenditure. Table 5 presents measures of the capital expenditure on properties within each segment. It should be recalled that capital expenditures in this dataset relate to non-recoverable spending by building owners and excludes amounts that could be recovered from tenants. This means that the rates are likely to understate the full cost of maintaining commercial property investments over time.

\section{Insert Table 5 here}

Overall, the amount of capital expenditure across a weighted all property portfolio is $0.5 \%$ of the capital value each year. Table 5 indicates that offices had the highest rates of capital expenditure and industrial buildings the lowest rates in this period. There is much less variation at a segment level than in the case of the depreciation rates. Shopping Centres and Retail Warehouses stand out as cases where owners have spent higher proportions of value in order to try and arrest depreciation, with apparently more success in the former than the latter case. The other result of note is that for City of London offices. Here, the low rate of expenditure coupled with the fairly low depreciation rate found earlier suggests that there may be something unusual about the assets held for long periods in this market, an issue also raised in the study by IPF (2010).

However, there has been some debate as to whether capital expenditure should be regarded as a deduction from income when measuring property performance (e.g. Young et al., 1995). Using rental values as a denominator allows some insight into the scale of such expenditures in relation to the potential income of each asset in the sample (bearing in mind that actual income will be determined by the lease contract in each case). Therefore, Table 5 sets out the expenditure relative to the rental value of the sample and shows that, on average, capital expenditure is 
equivalent to a $7 \%$ reduction in the annual rental value each year. For retail warehouses, the reduction represents almost $25 \%$ and, for Shopping Centres, $10 \%$.

Figure 3 presents the distribution of expenditure rates for the three main sector groups and the shopping centre and retail warehouse segments, using the rates computed as a percentage of capital value. It can be seen that the distributions are highly skewed, with many assets receiving either no or extremely low rates of capital expenditure over the period. In fact, over $40 \%$ of properties in the standard retail and office sectors received no capital expenditure, with the proportion lower for the industrial sector. This is perhaps surprising, although it must be remembered that only non-recoverable expenditure is being monitored in the dataset. ${ }^{8}$ The proportions of buildings receiving only small amounts ( $0 \%$ to $0.5 \%$ p.a.) of capital expenditure are also high in each case, whilst the office sector has the largest percentage of cases in the higher spending categories.

\section{Insert Figure 3 here}

A further question concerns the relationship between expenditure rates and the depreciation that occurred for each asset. In other words, were higher rates of capital expenditure associated with lower depreciation rates? Testing this proposition is not straightforward, since expenditure decisions are unlikely to be independent of the performance and depreciation of assets, and the distribution of expenditure rates in this dataset is truncated and highly skewed. These factors limit the usefulness of conventional correlation and regression analyses. However, the properties can be divided into groups based on the amount of expenditure they received, and the average depreciation of each group then compared. This was the approach taken here.

Panel $A$ of Table 6 reports, for the main three sectors, the number of assets and average depreciation rate for three different expenditure based groups. The first is comprised of properties that received no capital expenditure over the period, whilst the second is comprised of those that had only a minor amount of capital expenditure overall (greater than zero, but less than $0.5 \%$ of capital value p.a., on average). The final group consists of properties receiving expenditure of $0.5 \%$ p.a. of value or more. The $0.5 \%$ boundary is somewhat arbitrary, but was set to allow enough buildings into the highest spending group for meaningful statistical testing. A null hypothesis of no difference in the mean depreciation rate of two groups was then tested against an alternative hypothesis that assets in the group receiving more spending would show less depreciation. Results from t-tests of this hypothesis are reported in Panel B of Table 6.

\footnotetext{
${ }^{8}$ Blazenko and Pavlov (2004) argue that property managers prefer to make new investments than maintain existing ones. It is possible that the distribution of expenditure rates reflects this as well.
} 


\section{Insert Table 6 here}

Table 6 shows that the average depreciation rates for assets receiving most capital expenditure relative to capital value are lower than those for the other two groups, with the difference less pronounced for office buildings. This finding is reinforced by the equality of means tests, which show that the mean rates are significantly different from those of the no expenditure group for all three property types at the $10 \%$ level. In addition, for offices and industrial buildings, they are significantly different from the minor expenditure group at the $5 \%$ level. In contrast, average rates in the middle (minor) expenditure group are never significantly different from those of the no expenditure group, suggesting that small amounts of expenditure make little difference. However, this possibly reflects leasing and recording issues, as some minor expenditure on assets in the no expenditure group may have been recoverable from tenants, whilst other items may have been classified as maintenance. It is outside the scope of this paper but the question that remains is whether the expenditure added enough value to compensate for the outlay.

\section{Conclusion}

Rental depreciation is an important component in property investment decision making. For example, depreciation rates need to be factored into appraisals, especially those that model refurbishment / redevelopment options, whilst they also play an important role in asset allocation models and are necessary to identify retention rates for capital expenditure.

The literature review suggested that the longitudinal approach to measuring depreciation is theoretically sound and produces better measures of the relative decline in value through time of an existing property against a new version of the asset. It also suggests that depreciation rates cannot be considered in isolation of expenditure undertaken to arrest the decline and that no study is complete unless it reports both depreciation rates and rates of capital expenditure within the period of measurement.

There are practical issues with the application of the approach; for example, survivor bias, sample size versus time frame, and valuation issues with sample and benchmark. Using a 16 year time frame should have increased the stability of the results, but it does reduce sample size, plus it is data intensive owing to the necessity of matching every property with an appropriate benchmark. However, the alternative cross-sectional approach has major problems, not least the dependence of estimates on a single time point. Despite limitations, the longitudinal method produces robust 
estimates of both depreciation and capital expenditure rates given the data available. Since there is evidence that the sample used for this approach contains assets whose performance is relatively strong, the figures found might be considered conservative estimates of depreciation and expenditure rates as a result.

Rental depreciation rates for the standard retail, office and industrial sectors are $0.3 \%, 0.8 \%$ and $0.5 \%$ per annum, respectively, over the period 1993 to 2009 . These are net rates of depreciation that are supported by annual capital expenditure rates of $0.3 \%, 0.5 \%$ and $0.2 \%$, relative to capital value, for each of the three sectors, respectively. Results for the IPD PAS segments show that the sector level rates mask considerable variation at a segment level, particularly in the case of standard retail. In the office and industrial segments, the pattern of variation is not unexpected, but, in retail, the results are more difficult to interpret. In the case of office and industrial property, the land to building value ratio and the impact of different age cohorts needs further investigation.

It is clear that the issues surrounding the depreciation of retail property are not yet fully understood, as most emphasis in the real estate literature to date has been on office buildings. Further studies could usefully consider the way that retail values change in response to, for example, new developments, movements in the prime pitch over time and the relationship between land and building values, as well as issues surrounding the functionality and deterioration of the assets themselves. The impact of location on retail depreciation rates has not been fully investigated within the existing studies and remains an area that requires more analysis perhaps using detailed case studies of particular locations.

The shape of depreciation and the use of alternative aggregations (such as prime/secondary or age cohorts) have only been investigated briefly in this paper and there are few attempts at these tasks in the wider literature. The shape may well differ depending on the other possible influences discussed above; for example, it could be hypothesised that after a certain age, for some property types, the rate of depreciation should be much reduced, if not zero (e.g. see Colwell and Ramsland, 2003). It would be interesting to try and identify further the initial depreciation rate of new buildings. Functional obsolescence may appear overnight by a change in technology, so the design and flexibility of an asset is important. As data improves, more of these possible influences can be identified and included in the analysis.

One objective of the paper concerned capital expenditure and this study has measured the extent of capital expenditure within the sample and its impact on rental depreciation rates. The analysis indicates that the majority of properties have very little, if anything, spent on them through time and this has an impact on the rate of depreciation, an obvious but nonetheless important finding. 
The number of properties without refurbishment may be a function of particular UK lease structures, which have historically been long and have passed all repairing responsibilities to tenants. However, higher levels of capital expenditure are associated with lower rental depreciation rates and this should also impact on capital values/capitalisation rates. Nonetheless, there are issues about how expenditure rates are measured and communicated and the figures say little about the pattern of expenditure over time and in relation to an individual asset's age. If significant capital expenditure occurs in discrete lumps, it would be interesting for further research to consider whether properties that received it suffered greater depreciation in the preceding years and to what extent values were restored to benchmark levels thereafter. Furthermore, was subsequent depreciation less than that for other assets in its segment?

The fact that there are so many questions to be answered does not, in our opinion, diminish the findings that have been reported here. Most of these limitations come from the application of property market data which by its nature is difficult and expensive to collate. This is no different to most studies using property market data, some of which understate its limitations and the implications for the robustness of the results. These results represent the most comprehensive and up to date investigation of rental depreciation rates in the UK. They give a clear indication of the effect of the passage of time on the rates of rental value change and the capital expenditure figures give some context on the cost of keeping rental depreciation to the levels identified for each segment of the market.

\section{Acknowledgements}

The authors acknowledge the funding for this and related projects from the Investment Property Forum over a number of years and the provision of data by CBRE and Investment Property Databank, without which this research would not have been possible.

\section{References}

Barras, R. and Clark, P. (1996). Obsolescence and Performance in the Central London Office Market. Journal of Property Valuation and Investment. 14 (4): 63-78.

Baum, A. (1991). Property Investment Depreciation and Obsolescence. Routledge. London.

Baum, A. (1997). Trophy or Tombstone? A Decade of Depreciation in the Central London Office Market. Lambert Smith Hampton and HRES. London.

Baum, A and Crosby, N. (2007), Property Investment Appraisal (3e). Blackwell, Oxford. 
Baum, A. and Devaney, S. (2008), 'Depreciation, income distribution and the UK REIT', Journal of Property Investment and Finance. 26 (3): 195-209.

Baum, A. and Turner, N. (2004), 'Retention Rates, Reinvestment and Depreciation in European Office Markets', Journal of Property Investment and Finance, 22 (3): 214-235.

Blazenko, G. W. and Pavlov, A. D. (2004), 'The Economics of Maintenance for Real Estate Investments', Real Estate Economics, 32 (1): 55-84.

Bowie, N. (1984) The Depreciation of Buildings. Journal of Property Valuation and Investment. 2(1) : 5-13.,

CB Richard Ellis (2007), A Guide to the CB Richard Ellis Rent and Yield Monitor - Rent Index and Average Yields, Quarter 12007 , London: CB Richard Ellis.

CEM. (1999). The Dynamics and Measurement of Commercial Property Depreciation in the UK. College of Estate Management. Reading.

Colwell, P. F. and Ramsland, M. O. (2003). 'Coping with Technological Change: The Case of Retail', Journal of Real Estate Finance and Economics, 26 (1): 47-63.

Corgel, J. B. (2007), 'Technological Change as Reflected in Hotel Property Prices, Journal of Real Estate Finance and Economics, 34 (2): 257-279.

Crosby, N., Devaney, S. and Law, V. (2011), 'Benchmarking and valuation issues in measuring depreciation for European Office Markets', Journal of European Real Estate Research, 4 (1): 7-28.

Dixon, T. J., Crosby, N. and Law, V. K. (1999), A critical review of methodologies for measuring rental depreciation applied to UK commercial real estate, Journal of Property Research, 16 (2): 153-180.

Dunse, N. and Jones, C. (2005), 'Rental Depreciation, Obsolescence and Location: the Case of Industrial Properties', Journal of Property Research, 22 (2-3): 205-223.

Feldstein, M.S. and Rothschild, M. (1974). Towards an Economic Theory of Replacement Investment. Econometrica, 393-423.

Golton, B.L., (1989), Issues of economic obsolescence in building, Architect \& Surveyor,

September, pp $32-35$.

Hamelink, F. and Hoesli, M. (2004). Maximum Drawdown and the Allocation to Real Estate. Journal of Property Research. 21 (1): 5-29.

Hoesli, M. and MacGregor, B.M. (2000). Property Investment. Principles and Practice of Property Portfolio Management. Longman

Hotelling, H. (1925). A General Mathematical Theory of Depreciation. Journal of American Statistical Association. 20: 340-53.

Hulten C.R. and Wykoff, F.C. (1976). The Economic Depreciation of Non-Residential Structures. Working Paper in Economics No 16. John Hopkins University. Baltimore. 
Hulten C.R. and Wykoff, F.C. (1981a). The Estimation of Economic Depreciation Using Vintage Asset Prices: An Application of the Box-Cox Power Transformation. Journal of Econometrics. 15: 367-396

Hulten C.R. and Wykoff, F.C. (1981b). The Measurement of Economic Depreciation. In Hulten, C.R. (ed) Depreciation, Inflation and the Taxation of Income from Capital. Urban Institute Press, Washington DC, pp. 81-125.

Hulten C.R. and Wykoff, F.C. (1996). Issues in the measurement of economic depreciation: Introductory remarks. Economic Enquiry, 34 (1): 10-23.

IPD (2010), IPD UK Annual Property Digest 2009, London: Investment Property Databank.

IPF. (2004). Promoting More Flexible Investment in Property: Response to HM Treasury and Inland Revenue Consultation Document. July 2004. Investment Property Forum. London.

IPF. (2005). Depreciation in Commercial Property Markets. Investment Property Forum / IPF Educational Trust. London.

IPF (2010), Depreciation of Office Investment Property in Europe, London: Investment Property Forum.

JLW (1987). Obsolescence: the financial impact on property performance. Jones Lang Wootton. London.

Jones, C. (2009), 'Remaking the Monopoly Board: Urban Economic Change and Property Investment', Urban Studies, 46 (11): 2363-2380.

Jorgenson, D.W. (1996). Empirical Studies of Depreciation. Economic Enquiry, 34 (1): 24-42.

Knight, J. R. and Sirmans, C. F. (1996), 'Depreciation, Maintenance, and Housing Prices, Journal of Housing Economics, 5 (4), 369-389.

Law, V. (2004). The Definition and Measurement of Rental Depreciation in Investment Property. Unpublished PhD dissertation. University of Reading.

Leigh, W. A. (1980), 'Economic Depreciation of the Residential Housing Stock of the United States, 1950-1970', The Review of Economics and Statistics, 62 (2): 200-206.

Mansfield, J.R. and Pinder, J.A. (2008) "Economic" and "functional" obsolescence: Their characteristics and impacts on valuation practice", Property Management, 26 (3) : 191 206.

Nelson, R. A. and Caputo, M. R. (1997), 'Price Changes, Maintenance and the Rate of Depreciation', The Review of Economics and Statistics, 79 (3): 422-430.

Salway, F. (1986). Depreciation of Commercial Property. CALUS, Reading: College of Estate Management.

Turner, N. (2001). Property is not Microsoft. Paper presented at the IPD/GPR European Strategies conference, Wiesbaden, May.

Wurtzebach, C.H., Miles, M.E. and Alvin, A.L. (1984) Modern Real Estate (5e) Wiley : New York. 
Young, M. S., Geltner, D. M., McIntosh, W. and Poutasse, D. M. (1995), 'Defining Commercial Property Income and Appreciation Returns for Comparability to Stock Market-Based Measures', Real Estate Finance, 12 (2): 19-30.

Figure 1 - Industrial depreciation rates by cohort, 1993-2009

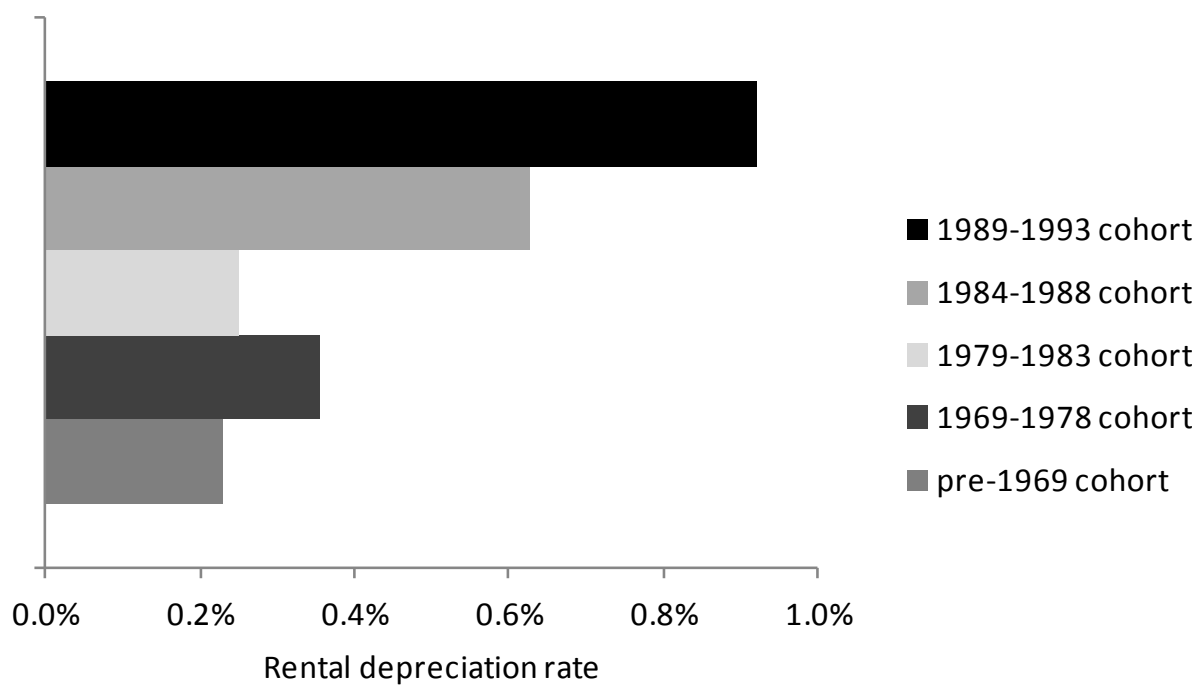

Figure 2 - Office depreciation rates by cohort, 1993-2009

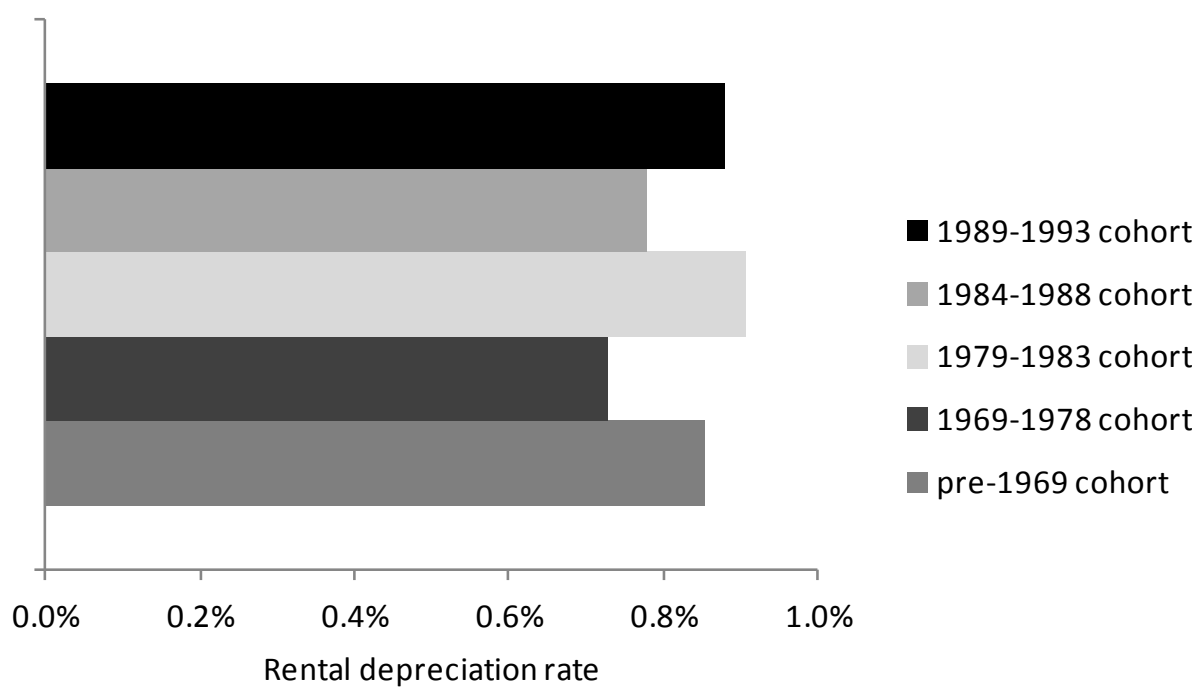


Figure 3 - Distribution of capital expenditure rates, 1993-2009

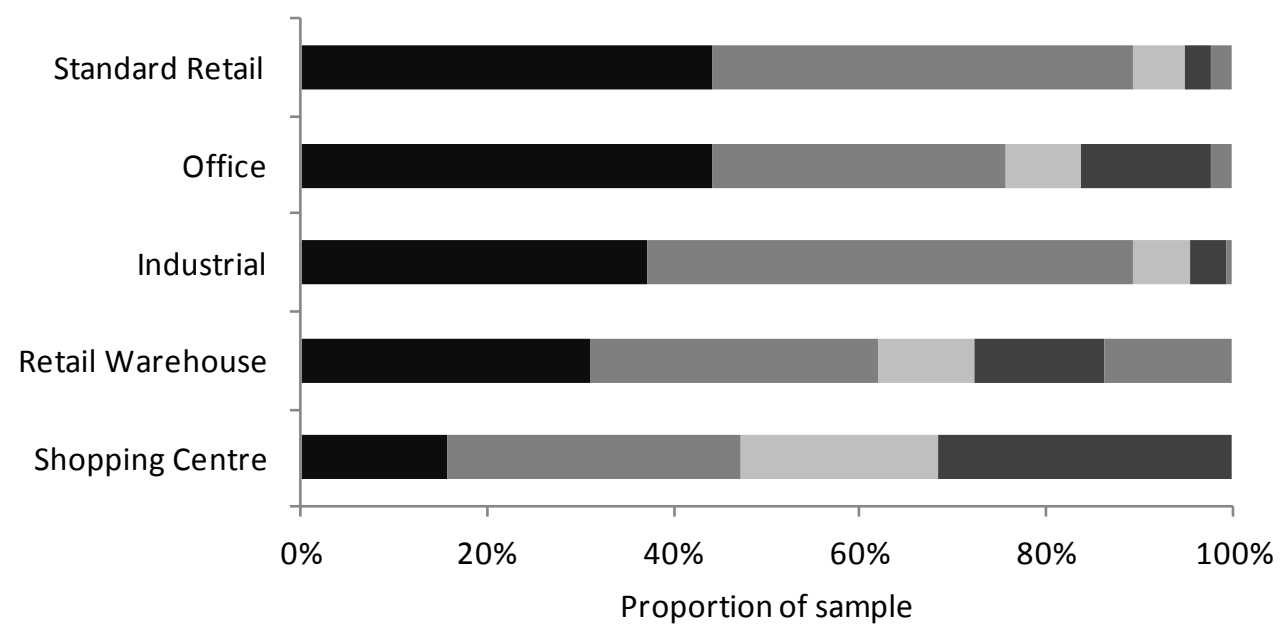

No expenditure $\quad 0-0.5 \%$ p.a. 0.5 - $1 \%$ p.a. $\square 1$ - $2.5 \%$ p.a. $\quad>=2.5 \%$ p.a.

Table 1: Number and value of properties in the sample

\begin{tabular}{lcccc}
\hline & $\begin{array}{c}\text { Number of } \\
\text { properties }\end{array}$ & $\begin{array}{c}\text { Capital value } \\
\text { end-1993 £m }\end{array}$ & $\begin{array}{c}\% \text { of IPF } \\
(2005) \text { sample }\end{array}$ & $\begin{array}{c}\% \text { of assets in } \\
\text { IPD at 1993 }\end{array}$ \\
\hline Standard Retails & 319 & 1,033 & $37 \%$ & $5 \%$ \\
Offices & 217 & 1,496 & $39 \%$ & $5 \%$ \\
Industrials & 158 & 762 & $47 \%$ & $7 \%$ \\
Std Ret - South East & 185 & 549 & $43 \%$ & $6 \%$ \\
Std Ret - Rest of UK & 134 & 484 & $32 \%$ & $4 \%$ \\
Shopping Centres & 19 & 411 & $26 \%$ & $6 \%$ \\
Retail Warehouses & 29 & 249 & $54 \%$ & $5 \%$ \\
Offices - City & 41 & 334 & $55 \%$ & $8 \%$ \\
Offices - West End & 64 & 402 & $38 \%$ & $6 \%$ \\
Offices - Rest of SE & 75 & 522 & $37 \%$ & $4 \%$ \\
Offices - Rest of UK & 37 & 237 & $33 \%$ & $3 \%$ \\
Industrials - SE & 104 & 556 & $50 \%$ & $8 \%$ \\
Industrials - Rest of UK & 54 & 206 & $44 \%$ & $6 \%$ \\
Total sample & 742 & 3,950 & $40 \%$ & $5 \%$ \\
\hline
\end{tabular}

${ }^{1}$ In terms of number of assets. Proportions are typically higher when measured in terms of value. 
Table 3: Rental depreciation by market segment, 1993-2009

\begin{tabular}{|c|c|c|c|c|}
\hline & $\begin{array}{l}\text { Number of } \\
\text { properties }\end{array}$ & $\begin{array}{c}\text { Benchmarks - } \\
\text { rental growth } \\
\text { p.a. }\end{array}$ & $\begin{array}{c}\text { Sample - } \\
\text { rental growth } \\
\text { p.a. }\end{array}$ & $\begin{array}{c}\text { Rate of rental } \\
\text { depreciation } \\
\text { p.a. }^{1}\end{array}$ \\
\hline Standard Retails & 319 & $3.2 \%$ & $2.9 \%$ & $0.3 \%$ \\
\hline Offices & 217 & $3.4 \%$ & $2.5 \%$ & $0.8 \%$ \\
\hline Industrials & 158 & $2.4 \%$ & $1.9 \%$ & $0.5 \%$ \\
\hline Std Ret - C London & 47 & $6.9 \%$ & $5.1 \%$ & $1.7 \%$ \\
\hline Std Ret - Rest of SE & 138 & $3.2 \%$ & $2.4 \%$ & $0.8 \%$ \\
\hline Std Ret - Rest of UK & 134 & $1.8 \%$ & $2.5 \%$ & $-0.7 \%$ \\
\hline Shopping Centres & 19 & $2.7 \%$ & $2.6 \%$ & $0.1 \%$ \\
\hline Retail Warehouses ${ }^{2}$ & 29 & $7.7 \%$ & $6.7 \%$ & $0.9 \%$ \\
\hline Offices - City & 41 & $2.2 \%$ & $1.7 \%$ & $0.5 \%$ \\
\hline Offices - West End & 64 & $5.6 \%$ & $4.5 \%$ & $1.1 \%$ \\
\hline Offices - Rest of SE & 75 & $2.8 \%$ & $2.0 \%$ & $0.8 \%$ \\
\hline Offices - Rest of UK & 37 & $3.0 \%$ & $1.1 \%$ & $1.8 \%$ \\
\hline Industrials - SE & 104 & $2.4 \%$ & $2.0 \%$ & $0.3 \%$ \\
\hline Industrials - Rest of UK & 54 & $2.4 \%$ & $1.4 \%$ & $1.0 \%$ \\
\hline All Property ${ }^{3}$ & - & - & - & $0.6 \%$ \\
\hline \multicolumn{5}{|c|}{${ }^{1}$ A negative figure denotes appreciation relative to benchmarks } \\
\hline \multicolumn{5}{|c|}{${ }^{2}$ Retail warehouses are measured for $1993-2006$ owing to data availability (see Section 3) } \\
\hline \multicolumn{5}{|c|}{${ }^{3}$ See discussion in section 3 for how this is estimated } \\
\hline
\end{tabular}


Table 4: Rental depreciation - mean, median, upper quartile and lower quartile rates

\begin{tabular}{lccccc}
\hline & $\begin{array}{c}\text { Unweighted } \\
\text { mean }\end{array}$ & $\begin{array}{c}\text { Lower } \\
\text { Quartile }\end{array}$ & Median & $\begin{array}{c}\text { Upper } \\
\text { Quartile }\end{array}$ \\
\hline Standard Retails & $0.4 \%{ }^{*}$ & $-1.0 \%$ & $0.4 \%$ & $1.5 \%$ & $2.5 \%$ \\
Offices & $1.0 \%{ }^{*}$ & $-0.1 \%$ & $1.1 \%$ & $2.1 \%$ & $2.2 \%$ \\
Industrials & $0.4 \%{ }^{*}$ & $-0.6 \%$ & $0.5 \%$ & $1.5 \%$ & $2.2 \%$ \\
Std Ret - C London & $1.9 \%{ }^{*}$ & $0.1 \%$ & $1.6 \%$ & $3.5 \%$ & $3.4 \%$ \\
Std Ret - Rest of SE & $0.7 \%{ }^{*}$ & $-0.2 \%$ & $0.7 \%$ & $1.7 \%$ & $1.8 \%$ \\
Std Ret - Rest of UK & $-0.5 \%{ }^{*}$ & $-1.6 \%$ & $-0.6 \%$ & $0.8 \%$ & $2.5 \%$ \\
Shopping Centres & $-0.2 \%$ & $-0.8 \%$ & $-0.2 \%$ & $0.7 \%$ & $1.5 \%$ \\
Retail Warehouses & $1.6 \%{ }^{*}$ & $0.5 \%$ & $1.3 \%$ & $2.8 \%$ & $2.4 \%$ \\
Offices - City & $0.4 \%$ & $-0.5 \%$ & $0.3 \%$ & $2.0 \%$ & $2.4 \%$ \\
Offices - West End & $1.0 \%{ }^{*}$ & $-0.2 \%$ & $1.0 \%$ & $2.1 \%$ & $2.3 \%$ \\
Offices - Rest of SE & $1.0 \%{ }^{*}$ & $-0.1 \%$ & $0.9 \%$ & $2.0 \%$ & $2.1 \%$ \\
Offices - Rest of UK & $1.8 \%{ }^{*}$ & $1.2 \%$ & $2.0 \%$ & $2.4 \%$ & $1.2 \%$ \\
Industrials - SE & $0.1 \%$ & $-0.9 \%$ & $0.3 \%$ & $1.2 \%$ & $2.0 \%$ \\
Industrials - Rest UK & $1.0 \%{ }^{*}$ & $0.2 \%$ & $1.4 \%$ & $1.9 \%$ & $1.7 \%$ \\
\hline${ }^{*}$ denotes significance from zero at the 5\% level & & & & \\
${ }^{1}$ Retail warehouses are measured for 1993-2006 owing to data availability (see Section 3) & \\
\hline
\end{tabular}


Table 5: Capital expenditure rates by market segment, 1993-2009

\begin{tabular}{lccc}
\hline & $\begin{array}{c}\text { Number of } \\
\text { properties }\end{array}$ & $\begin{array}{c}\text { as \% of } \\
\text { annual capital } \\
\text { values }\end{array}$ & $\begin{array}{c}\text { as \% of } \\
\text { annual rental } \\
\text { values }\end{array}$ \\
\hline Standard Retails & 319 & $0.3 \%$ & $4.6 \%$ \\
Offices & 217 & $0.5 \%$ & $6.8 \%$ \\
Industrials & 158 & $0.2 \%$ & $3.0 \%$ \\
Std Ret - C London & 47 & $0.2 \%$ & $2.9 \%$ \\
Std Ret - Rest of SE & 138 & $0.3 \%$ & $3.8 \%$ \\
Std Ret - Rest of UK & 134 & $0.4 \%$ & $5.8 \%$ \\
Shopping Centres & 19 & $0.9 \%$ & $10.0 \%$ \\
Retail Warehouses & 29 & $1.5 \%$ & $23.3 \%$ \\
Offices - City & 41 & $0.2 \%$ & $4.0 \%$ \\
Offices - West End & 64 & $0.5 \%$ & $6.6 \%$ \\
Offices - Rest of SE & 75 & $0.7 \%$ & $8.6 \%$ \\
Offices - Rest of UK & 37 & $0.5 \%$ & $5.9 \%$ \\
Industrials - SE & 104 & $0.2 \%$ & $3.0 \%$ \\
Industrials - Rest of UK & 54 & $0.3 \%$ & $3.1 \%$ \\
All Property & & $0.5 \%$ & $7.0 \%$ \\
\hline${ }^{1}$ See discussion in section 3 for how this is estimated & & \\
\hline
\end{tabular}




\section{Table 6: Rental depreciation rates of different expenditure-based groups}

\begin{tabular}{lccc}
$\begin{array}{lcc}\text { Panel A: Average rental depreciation } \\
\text { G1: No exp. }\end{array}$ & G2: Minor exp. & G3: Major exp. \\
\hline Standard retails & $0.6 \%$ & $0.3 \%$ & $-0.1 \%$ \\
Offices & $\mathrm{n}=141$ & $\mathrm{n}=144$ & $\mathrm{n}=34$ \\
& $1.1 \%$ & $1.2 \%$ & $0.7 \%$ \\
Industrials & $\mathrm{n}=96$ & $\mathrm{n}=68$ & $\mathrm{n}=53$ \\
& $0.4 \%$ & $0.6 \%$ & $-0.3 \%$ \\
& $\mathrm{n}=59$ & $\mathrm{n}=82$ & $\mathrm{n}=17$
\end{tabular}

Panel B: Equality of means $-p$ values ${ }^{1}$

\begin{tabular}{lccc} 
& G1 vs. G2 & G1 vs. G3 & G2 vs. G3 \\
\hline Standard retails & 0.14 & 0.05 & 0.15 \\
Offices & 0.63 & 0.09 & 0.05 \\
Industrials & 0.83 & 0.07 & 0.01 \\
\hline
\end{tabular}

${ }^{1}$ One tailed tests where $\mathrm{H}_{0}: \bar{x}_{a}-\bar{x}_{\bar{b}}=0$ and $\mathrm{H}_{1}: \bar{x}_{\bar{a}}-\bar{x}_{\bar{b}}>0$, with 'a' as the group in which less expenditure occurred 